\title{
Review
}

\section{Factors Affecting Rumen Microbial Protein Synthesis: A Review}

\author{
Abdukarim Y. Harun, DVM [Student]*; Kedir Sali, DVM [Student]
}

College of Veterinary Medicine, Haramaya University, Haramaya, Ethiopia

"Corresponding authors

Abdukarim Y. Harun, DVM [Student]

College of Veterinary Medicine, Haramaya University, Haramaya, Ethiopia; Tel. +25 193563 I697; E-mail: Karuyuyel0@gmail.com

Kedir Sali, DVM [Student]

College of Veterinary Medicine, Haramaya University, Haramaya, Ethiopia; Tel. +25192 I85976I; E-mail: kedirsali@yahoo.com

\section{Article information}

Received: April 3 $3^{\text {rd }}, 2019$; Revised: May 13 ${ }^{\text {th }}, 2019$; Accepted: July 15 $5^{\text {th }}, 2019$; Published: August I ${ }^{\text {st }}, 2019$

\section{Cite this article}

Harun AY, Sali K. Factors affecting rumen microbial protein synthesis:A review. Vet Med Open J. 2019; 4(I): 27-35. doi: I0.17/40/VMOJ-4-I33

\section{ABSTRACT |}

There is a diversified microbial ecosystem in the rumen for efficient utilization of diet by providing essential nutrient to their host. But there are different factors affecting rumen microbial protein synthesis which are physical factors, chemical factors, dietary factors, biological factors and endogenous factors. Among the details of factors, dietary factors and ruminal $\mathrm{pH}$ are the dominant factors influencing rumen microbial protein production. The effects of some dietary factors, on the amount and efficiency of microbial protein synthesis, are discussed in this review. Specifically, these factors include forage quality diets, level of feed and types of feed. It seemed that diets containing a mixture of forages and concentrates increase the efficiency of microbial protein synthesis because of an improved rumen environment for the growth of more diverse bacterial species. This review describes physical and chemical factors which include: $\mathrm{pH}$ and buffer system, oxygen concentration, rumen outflow rate and synchronized release of nitrogen and energy from the diet, a nitrogen compound, energy spilling, vitamins and minerals and antimicrobials chemicals, respectively. Age, species, physiological status, sex, and stress are among endogenous factors that mostly affect microbial protein synthesis of a ruminant. Bacteriophages, protozoa predation and bacterial lysis are biological factors affecting the efficiency of microbial protein synthesis. All these factors have a direct effect on the synthesis of microbial protein in the rumen. Therefore, the cumulative effects of the above factors are resulted in the depopulation of rumen microflora and finally reduction of animal product. So, improvement in quantitative aspect of microbial protein synthesis solves many problems from simple to complex so that, the quantitative aspect of rumen microbial biomass are invaluable for health and productivity of ruminants than qualitative aspect hence, maintain health rumen ecosystem means having healthy ruminant.

\section{Keywords}

Rumen; pouvoir hydrogène (pH); Microbial protein; Rumen ecosystem; Ruminant; Rumen microflora; Nutrient; Haematological parameters reference ranges; Healthy status.

\section{Abbreviations}

MBP: Microbial protein; MCP: Microbial crude protein; NDF: Neutral detergent fiber; NPN: Non-protein pitrogen; NSC: Nonstructural carbohydrate; OM: Organic matter; OMTDR: Organic matter truly digested in rumen; RDP: Rumen degradable protein; RUP: Rumen undegradable protein; SCFA: Short chain fatty acid; TDN: Total digestible nutrient; VFA: Volatile fatty acid; ATP: Adenosine Tri-phosphate; CP: Crude protein; CS: Concentrate supplementation; DM: Dry matter; DOMI: Dry organic matter intake; EMPS: Efficiency of microbial protein synthesis; FOM: Fermented organic matter.

\section{INTRODUCTION}

$\mathrm{R}$ uminants have diversified microbial ecosystem consisting of bacteria (1010-1011 cells/mL), ciliate protozoa (104-106/
$\mathrm{mL})$, anaerobic fungi (103-105 zoospores/mL) and bacteriophages (108-109/ mL). The synergism and antagonism among the different groups of microbes and even among different genera of the same group is so diverse and complicated that it is difficult to 
quantify the role played by any particular group of microbes present in the rumen. The net result of these reactions in the rumen is responsible for the bioconversion of feed into a form that is utilizable by the animal as a source of energy (short-chain volatile fatty acids) and microbial protein (as single-cell protein). ${ }^{1}$

Ruminants are distinguished from the rest of the animals by the morpho-physiological adaptation of the upper part of their stomach. This peculiarity allows them to turn roughages and low quality protein, even non-protein nitrogen (NPN) into quality nutrients for themselves such as microbial protein and volatile fatty acid. ${ }^{2}$ Microbial protein synthesis is important in ruminants because microbial protein synthesized in the rumen provides $50 \%$ of amino acids required for ruminants. Synthesis of microbial protein and growth of ruminal microbes largely depend on adequate energy (ATP), resulting from the fermentation of organic matter in the rumen, and $\mathrm{N}$ resulting from degradation of non-protein and protein nitrogen sources and this can be affected by either natural or diet-related factors. ${ }^{3}$ Ruminants' foregut microbial community the structure could be expected to be constrained by, physical, chemical, physiological, and even biological characteristics that evolved along with the varied feeding strategies in the various ruminant lineages. ${ }^{4}$

Adaptation has resulted in a diversity of rumen sizes and passage rates of rumen contents, allowing ruminant species to exploit a range of feed types. In addition, feed composition effects, and the host adaptations might also play a role in regulating rumen microbial community structure. Host and diet effects on rumen microbial community structure could be separated. Microbial communities could clearly be discriminated by both host and diet, with bacteria being the main drivers behind the observed differences. This probably reflects their more diverse metabolic capabilities compared with the less versatile archaea and protozoa. ${ }^{4}$

Among the factors that affect the synthesis of microbial protein, the availability and synchronization between energy and nitrogen compounds $(\mathrm{N})$ in the rumen have been recognized as the most important factor. Although the other most important factors such as dietary factors, animal factors, biological and chemical factors can influence the efficiency of microbial protein synthesis in the rumen. ${ }^{5}$

Therefore, this paper is to highlight major factors affecting the rumen microbial protein synthesis.

\section{FACTORS AFFECTING MICROBIAL PROTEIN SYNTHESIS IN THE RUMEN}

Due to the complexity of microbial protein synthesis, there are many factors affecting the performance of the same. ${ }^{2}$ The contributions of energy and nitrogen in the rations, as the most limiting factors for microbial protein synthesis in the rumen, ${ }^{6}$ although other nutrients such as sulfur, volatile fatty acids, fatty acids of branched-chain, minerals and vitamins, are also very important for microbial growth, which is in a lesser extent. ${ }^{7}$

\section{Physical Factors}

pH and buffer system: One of the important factors affecting on the level of synthesis of microbial protein in the rumen is the acidity of the forage pouvoir hydrogène $(\mathrm{pH}) .{ }^{8}$ Functional performance of rumen will be greater when rumen $\mathrm{pH}$ is above 6.0 and $\mathrm{pH}$ above 5.7 is necessary for protein synthesis. When rumen $\mathrm{pH}$ fell below 6, microbial enzymes in rumen do not function effectively and bacterial growth decline markedly. ${ }^{9}$

Cerrato-Sánches et $\mathrm{al}^{10}$ reported that the negative effect on rumen fermentation started as soon as $\mathrm{pH}$ decreased to 5.50. However, fiber digestion rates decrease when ruminal $\mathrm{pH}$ declines below 6.00-6.20 which reduces access of bacteria and enzymes to the protein thus decreasing crude protein degradability. ${ }^{11} \mathrm{~A}$ low $\mathrm{pH}$ value is also expected to reduce the digestibility of fibrous plant tissues and due to low $\mathrm{pH}$ value, the energy within the rumen is diverted to non-growth functions, i.e. maintaining neutral $\mathrm{pH}$ in bacterial cells. ${ }^{12}$ Apart from affecting congenital prosopagnosia (CP) degradation, rumen $\mathrm{pH}$ could also affect membrane co-factor protein (MCP) synthesis, the efficiency of MCP synthesis and yield of MCP which are affected by rumen $\mathrm{pH}$ and outflow rate of solid particles and liquid from the rumen. ${ }^{13}$ Different bacterial species grow in different $\mathrm{pH}$ range; for instance, cellulolytic bacteria are sensitive to acid $\mathrm{pH}$; whereas, amylolytic species are more acid tolerant. $^{12}$

Rumen $\mathrm{pH}$ is largely a function of the volatile fatty acid (VFA) concentration, ${ }^{14,15}$ and $\mathrm{pH}$ will drop if there is a reduced rate of VFA absorption. ${ }^{16}$ In a diet with high neural stem cell (NSC) and rumen degradable protein (RDP), VFA concentrations are high and ruminal $\mathrm{pH}$ is low. ${ }^{17}$ Feed intake and salivary secretion affect $\mathrm{pH}$ in the rumen. ${ }^{18}$ At a higher level of feed or dry matter (DM) intake, the $\mathrm{pH}$ of the rumen is lower. ${ }^{17}$

Rumen under normal conditions has $\mathrm{Na}^{+}, \mathrm{K}^{+}$, bicarbonate and short-chain fatty acids as the main buffering component. Forages encourage buffering through increased salivation and cation exchange of fiber. ${ }^{9}$ The rumen is usually well buffered, due to the presence of bicarbonates and phosphates founded in the continuous flow of saliva. ${ }^{19}$ Rumen, although well buffered by bicarbonate, phosphate, protein and VFA can vary in $\mathrm{pH}$ from approximately 7.0 to less than 5 under different dietary condition. ${ }^{20}$ Rumen buffering could avert the reduction in $\mathrm{pH}$ and could enhance rumen microbial growth, diversity and activity, fermentation end product and microbial protein synthesis. ${ }^{21}$ Ammonia from degraded protein or NPN would also act as a buffer in the regulation of the ruminal $\mathrm{pH} .{ }^{16}$ The rumen is well buffered by salivary secretion; however, if the amount of dietary non-deliverable forward (NDF) is restricted and the rate of carbohydrate fermentation is fast, the $\mathrm{pH}$ may decline. ${ }^{12}$

Oxygen concentration: The rumen is a suitable environment for the development of a large number of anaerobic microorganisms, having unique characteristics such as temperature around 38 to 42 ${ }^{\circ} \mathrm{C} .22$ But normally, the temperature was more commonly found to 
be $39{ }^{\circ} \mathrm{C} \cdot{ }^{23,24}$ Rumen environment is anaerobic, and hence most of the bacteria are obligate anaerobes. Some of them are so sensitive to oxygen that these are killed on exposure to oxygen. ${ }^{1}$ Oxygen sequestration up to $16 \mathrm{~L}$ of $\mathrm{O}_{2}$ can enter the rumen daily through water intake, rumination, and salivation, and inhibit the growth of obligate cellulolytic anaerobes like Fibrobacter succinogenes. So, yeasts can make the rumen environment more conducive for anaerobic, autochthonous microbes by scavenging $\mathrm{O}_{2} \cdot{ }^{25}$ About 10 to 20 liters/ day of $\mathrm{O}_{2}$ could enter from capillaries through the mucosal lining. Strictly anaerobic species, e.g. methanogens, survive in the rumen under $\mathrm{O}_{2}$ tensions previously found to be inhibitory to these organisms. Therefore, the ruminal microbial population must be able to rapidly utilize $\mathrm{O}_{2}$ and remove it from the environment of highly $\mathrm{O}_{2}$ sensitive organisms. ${ }^{26}$

Rumen outflow rate: It is one of the important factors which influencing the level of synthesis of microbial protein in the rumen is the rate of passage of food masses through the rumen. Passage of food masses through the rumen at high-speed increases the number of microorganisms without high energy consumption. Faster outflow rate is visualized to reduce the maintenance expenses of microorganisms (microbes) since they contribute less time inside the rumen. ${ }^{27}$ According to the Agricultural and Food Research Council (AFRC) ${ }^{28}$ data increasing the rate from 0.02 to 0.08-hours increases the level of synthesis of microbial protein in the rumen to $20 \%$. The presence of dry matter in the forage increases the rate of passage of food passes through the rumen and the level of synthesis of microbial protein in the rumen. Rumen outflow rate is a function of dry matter intake and therefore it can be assumed that the efficiency of microbial protein synthesis in the rumen can be increased as dry matter intake increases (5 and 13). Level of DM intake, the residence time in the rumen and fractional outflow rate has an effect on degradability and extent of cerebral palsy (CP) degradation in the rumen. ${ }^{29}$

The rate of passage of ingested feed depends on the feed intake by the animal, ${ }^{30}$ and the improvement of growth and microbial efficiency is due to a reduction in the maintenance requirements of the microorganisms. ${ }^{31}$ Therefore, ensuring an adequate intake of dry matter is a way of increasing the production of MCP and reducing the need of rumen undegradable protein (RUP) in the diets. ${ }^{32}$ The increased passage of microbial protein to the small intestine occurred as a result of the increased passage of both fluids and solids with increased intake. ${ }^{33}$

\section{Chemical Factors}

Synchronized release of nitrogen and energy from diet: Synchronization means both energies in the form of carbohydrates or organic matter $(\mathrm{OM})$ and protein in the form of $\mathrm{N}$ or peptides are available in the rumen throughout the day, and neither OM nor $\mathrm{N}$ is exceeded or limited for maximal microbial synthesis at any point of time. Synchronization of rumen available protein and energy is one of the conceptual methods to increase the efficiency of utilization of nutrients by the ruminants. Formulation of diets that are synchronous for energy and nitrogen release in the rumen has been shown to increase the efficiency of maltose-binding protein
(MBP) synthesis in the rumen. ${ }^{34}$ Matching the release of ammonia$\mathrm{N}$ from dietary protein with the release of usable energy may improve $\mathrm{N}$ utilization. ${ }^{5}$

Synchronizing energy and $\mathrm{N}$ availabilities in the rumen seems to have the potential to enhance the output of microbial protein from the rumen and efficiency of ruminal fermentation, thereby improving feed utilization and animal performance. ${ }^{35}$ The optimal RDP balance of a diet is close to zero and corresponds to rumen degradable $\mathrm{N}$ to fermented $\mathrm{OM}$ ratio equal to $25 \mathrm{~g}$ of $\mathrm{N} / \mathrm{kg}$ of fermented organic matter (FOM), which reflects a wellbalanced availability of energy and $\mathrm{N}$ to rumen microbes. When the RDP balance is positive for a diet, $\mathrm{N}$ losses from the rumen occur. Negative RDP balance indicates a shortage of nitrogen and consequently, the microbial activity may be impaired. Matching degradation of carbohydrate and protein rates of degradation in rumen allows efficient MBP yield and overall dietary protein incorporation. ${ }^{36}$

Nitrogen compound: Rumen microorganisms act normally if the level of raw protein in the feed is more than $11 \%$. To ensure the growth and progression of rumen microorganisms it is important to use feed with nitrogenous compounds in the feed. Nitrogenous compounds and degradability of feed proteins in the rumens are important for meeting the needs protein in ruminants in protein. And modern protein systems indicate that microorganisms' requirement for nitrogen is satisfied by a degrading protein in the rumen, yielding oxidized amino acids and nitrogen, 5,8 Showed that nitrogen compounds, which are released during the protein degradation, are crucial for microbial growth in the rumen. It seems that proteins which have lower rates of ruminal degradation tend to improve the efficiency of microbial protein synthesis, probably because of the better capture of released $\mathrm{N}$ by rumen microbes.

Microbial protein is largely dependent upon the availability of energy generated by the fermentation of carbohydrates. On average, 20 grams of bacterial protein is synthesized per 100 grams of organic matter fermented in the rumen. The percentage of protein in bacteria ranges from 38 to $55 \%$. Non-protein nitrogen from the feed and urea recycled into the rumen through saliva or the rumen wall also contribute to the pool of ammonia in the rumen. In addition, ruminants possess a mechanism to spare nitrogen. When feeding a low nitrogen diet, large amounts of urea (typically excreted in the urine) recycles into the rumen, where it can be used again by the microbes. If ammonia levels in the rumen are too low, there will be a shortage of nitrogen available to bacteria and feed digestibility will be reduced. ${ }^{5}$

Energy spilling: Energy spilling is energy dissipated as heat when the amount of ATP available from the fermentation of feedstuff exceeds the amount used for growth and maintenance. ${ }^{37}$ Energy spilling can be a major detraction from efficient growth in bacteria. Those bacteria that spill energy fermented glucose 10 -fold faster than those that did not. ${ }^{38}$ Energy spilling diverts energy away from growth, decreasing the efficiency of the microbial growth and thus the amount of microbial protein available for digestion. Energy spilling has been measured in rumen bacteria but could 
not be in rumen protozoa (which make-up $10-50 \%$ of the microbe biomass. ${ }^{39}$

Vitamins and minerals: In addition to $\mathrm{N}$ and carbohydrate supply, the microbial yield is affected by the concentrations of trace minerals and vitamins. Dietary sulfur concentration has been found to affect microbial growth. ${ }^{7}$ The amount of sulfur required by rumen microorganisms for the synthesis of methionine and cysteine ranges from 11 to $20 \%$ of the total diet based on the status of the cattle. ${ }^{29}$ Limited intake of sulfur may restrict microbial protein synthesis when large amounts of non-protein nitrogen are fed to ruminant animals, such as urea. ${ }^{7}$ Sodium sulphate and methionine have been shown to stimulate riboflavin and B12 vitamin synthesis by rumen microorganisms to a greater extent than cysteine or elemental sulphur. It is essential in the synthesis of sulphur containing amino acids that are needed in the elaboration of the MBP. ${ }^{40}$ Phosphorus $(\mathrm{P})$ is another mineral required for the synthesis of ATP and protein by rumen microbes. Microbial protein synthesis can be limited by an insufficient supply of P for microbial growth.

Magnesium activates many bacterial enzymes including phosphohydrolases, phosphor transferases and pathways involving ATP and thiamine pyrophosphate reactions. Its concentration in the ribosomes makes it essential for the protein synthesis process but it can be partly replaced by manganese. ${ }^{9}$ Vitamin B2 is required only $0.38 \mathrm{mg} / \mathrm{d}$ but pantothenic acid (B5) is required about 360 $\mathrm{mg} / \mathrm{d}$ to dairy cows for the optimum rumen fermentation. MBP production in control, water and fat-soluble vitamins were 163 and $140 \mathrm{~g} / \mathrm{d}$, respectively thus, indicating B-complex vitamin supplementation improves rumen MBP production. ${ }^{41}$

Antimicrobial chemicals: Effect of plant extracts like garlic and ginger extracts were found to have decreased the protozoa population resulting in a reduction of methane emission in the rumen and thus inhibiting methanogenesis and decrease rumen protein production. The other one is essential oils in the rumen which resulted in the reduction of protein and starch degradation, due to selective action on certain rumen microorganisms like Gram-positive bacteria due to the barrier of the cell wall structure not tolerating the inflow of the secondary metabolites. ${ }^{42}$ Ionophores (such as monensin, lasalocid, laidlomycin, salinomycin and narasin) are antimicrobial compounds that are commonly fed to ruminant animals to improve feed efficiency. These antimicrobials specifically target the ruminal bacterial population. They are lipophilic compounds that exert their effects at the membrane level, and are most effective against gram-positive bacteria and alter the microbial ecology of the intestinal microbial consortium. Ionophores transport ions across cell membranes of susceptible bacteria, dissipating ion and uncoupling energy expenditures from growth, killing these bacteria. ${ }^{43}$ The efficiency of microbial protein synthesis was greater in forages containing saponin and tannins, which reduce ruminal $\mathrm{N}$ degradability. ${ }^{5}$ The readily degradable fraction of protein is higher in forages than in grains. Approximately $40 \%$ of the protein in fresh alfalfa is soluble in the rumen environment. ${ }^{44}$

\section{Dietary Factors}

Forage quality: The yield and efficiency of synthesis of microbial protein have frequently been recorded as high (30-45 g microbial$\mathrm{N}$ per $\mathrm{kg} \mathrm{OM}$ apparently digested in the rumen), when high-quality grass is grazed. ${ }^{45,46}$ Much lower microbial efficiencies $(<20 \%)$ have been noted with lower-quality autumn-grass, though in these experiments season was confounded with the physiological state of the animals. ${ }^{46}$ MPS is often increased by supplementing silage-based diets with moderate levels of readily-fermented carbohydrates. ${ }^{47,48}$

Level of feed: Increasing the level of feeding in ruminants is expected to reduce maintenance costs of microbes because they spend less time within the rumen. ${ }^{2}$ Experimental evidence is available which suggest that the frequency of feeding improve the efficiency of microbial protein synthesis and was certainly observed through stimulation models of rumen function. Also, frequent feeding increases the rate of passage of liquid and solids from rumen and influence in microbial protein synthesis so, increasing the feeding frequency of dried grass meal from 2 to 8 times increased MBP synthesis from 36 to $46 \mathrm{~g} / \mathrm{kg}$ of dry organic matter intake (DOMI). ${ }^{27}$ The level of feeding effect appears to hold true for maximum electronic music plotting system (EMPS) since there are no occurrences of high EMPS at low intakes. ${ }^{28}$ However, no significant effect was found in the diets containing rolled barley which indicated that the frequency of feeding leads to increase in MBP production mainly due to the impact on the roughage diet. Feeds associated with lower outflow rates, for example, processed-grain rations, have a higher total energy production but lower efficiency of MBP production. ${ }^{9}$ Therefore increased feeding frequency should lessen variation in ruminal ammonia $\mathrm{N}$ concentration and improve microbial protein yield. ${ }^{49}$

Types of feed: The efficiency of microbial protein synthesis greatly differs in animals fed different diets, even within similar diets. The average efficiency of microbial protein synthesis was $13.0 \mathrm{~g}$ membrane cofactor protein (MCP)/100 g organic matter truly digested in the rumen (OMTDR), ranging from 7.5 to 24.3 for forage-based diets. For mixed forage-concentrate diets, the average efficiency of microbial protein synthesis was $17.6 \mathrm{~g} \mathrm{MCP} / 100 \mathrm{~g}$ OMTD in the rumen, ranging from 9.1 to $27.9 \mathrm{~g} .{ }^{3}$ Efficiency of microbial protein synthesis for high concentrate diets was $13.2 \mathrm{~g}$ MCP/100 $\mathrm{g}$ OMTD in the rumen, ranging from 7.0 to 23.7 . Overall, the average efficiency of microbial protein synthesis is $14.8 \mathrm{~g}$ MCP $/ 100 \mathrm{~g}$ OMTD in the rumen, ranging from 7.0 to $27.9 \mathrm{~g} \mathrm{MCP} / 100 \mathrm{~g}$ of OM truly digested in the rumen. ${ }^{29}$

The efficiency of microbial protein synthesis was predicted to be around $13 \mathrm{~g} \mathrm{MCP} / 100 \mathrm{~g}$ of total digestible nutrient (TDN) for beef cows. Sources of carbohydrates, such as different ratios of structural to nonstructural carbohydrates, would have little effects on the efficiency of microbial protein synthesis. It is well known that the rapid digestion of nonstructural carbohydrate results in reduced ruminal $\mathrm{pH}$. The efficiency of microbial protein synthesis is reported to be low in animals fed high-concentrate diets because of reduced ruminal $\mathrm{PH} \cdot{ }^{36}$ Also, the efficiency of MBP production varied widely between forages. MBP production in grass and maize silages was from 115 to 158 and 165 to 217, respectively while with green forage and hay was 145 to 199 and 126 $\mathrm{g} / \mathrm{kg}$ of fermentable OM. ${ }^{3}$ 


\section{Biological Factors}

Bacteriophages: Bacteriophages are the viruses of bacteria and are reported to be present in the rumen in large numbers. ${ }^{1}$ The phage densities ranging from 109 to 1010 particles per milliliter of rumen fluid and considerable morphological diversity has been observed, with 26-40 morphologically distinct types from three viral families (Myoviridae, Siphoviridae, and Podoviridae) being reported. ${ }^{50} \mathrm{Vi}$ ruses of prokaryotes (phages) are ubiquitous to the gastrointestinal tracts of all animals, and particularly dense and diverse populations occur in the rumen of herbivores these viruses have characteristics that can be both detrimental (reduce feed efficiency, transfer toxin genes) and advantageous (bacterial population balance, lateral gene transfer, phage therapy, novel enzymes), very little is known about their biological properties or genetic make-up. ${ }^{51}$ One cause of reduced efficiency is the non-specific lysis of bacteria within the rumen and subsequent fermentation of the bacterial protoplasm. This phenomenon has not been explained but at times a large proportion of the bacterial pool can be affected. ${ }^{52}$ Bacteriophages (bacterial viruses) are implicated in this lysis. Bacteriophages are obligate pathogens of bacteria and occur in dense populations in the rumen ${ }^{53}$ Because, they lyse their bacterial hosts within the rumen and, the process is identified as reducing the efficiency of feed..$^{50}$

Protozoa predation: Protozoa engulf bacteria and digest them to cover their nutritional needs. Bacterial proteins are degraded into peptides and amino acids inside the protozoa. Nearly half of the ingested amino acids are used by ciliates. The other half reappears in the medium where they are deaminated by bacteria as it was calculated that as much as $90 \mathrm{~g}$ of bacterial dry matter can be engulfed by protozoa each day in a sheep rumen, which corresponds to a loss of $27 \mathrm{~g}$ of bacterial protein. As a consequence of the predation, the turnover of bacterial protein is increased by the presence of protozoa. ${ }^{40}$ Protozoa predate on bacteria as their main protein source and as a result, defaunation makes the rumen more efficient in terms of proteosynthesis increasing the duodenal flow of microbial protein $(+30 \%, p<0.001)$ and total non-ammonia $\mathrm{N}$ flow $(+31 \%, p<0.001)$. Defaunation also increased the efficiency of microbial protein synthesis $(+27 \%, p=0.008)$ as a result of both better microbial proteosynthesis and a lower OM digestion. Protozoal generation time is far higher than that of bacteria, thus the energetic requirements for maintenance are higher when expressed as a ratio of protein leaving the rumen. ${ }^{54}$ As a result, the presence of protozoa has a negative impact on the overall energetic efficiency of the rumen ecosystem. In addition, defaunation can also modify the composition of rumen bacteria. ${ }^{55}$ The ability of protozoa to engulf exogenous fatty acids ${ }^{56}$ may divert more carbon toward VFA production in preference to fatty acid synthesis and ultimately increase VFA production. On the basis of stoichiometry, such a shift in rumen VFA production should result in a decrease in methane production as less metabolic $\mathrm{H}_{2}$ will be available as a substrate for methanogenesis. ${ }^{57}$

The effect of the presence of rumen protozoa on pathogen's survival in the rumen and pathogen shedding is another area of interest. As noted above rumen protozoa engulf and digest a wide range of bacteria ${ }^{54}$ and can reduce the shedding of potential pathogens from the animal, although the effect is highly dependent on the composition of the protozoal population present. ${ }^{58}$ However, it has also been shown that rumen protozoa enhance the pathogenicity of certain pathogens leaving the rumen ${ }^{59}$ suggesting that more work is needed in this area.

Bacterial Lysis: The microbial turnover is estimated in defaunated sheep using $\mathrm{N}$ and autolysis of bacteria in the rumen environment. In gram-positive rods first deposited peptidoglycan at the inner surface while their outer layers were cut by autolytic enzymes and stress is gradually transferred to more recently synthesized portions of the peptidoglycan. The low $\mathrm{pH}$, in turn, would inhibit autolysis. Conversely, starvation could dissipate the membrane potential, increase $\mathrm{pH}$, and activate the autolysins. Compounds those decreases the membrane potential accelerates the lysis of rumen bacterium. However, bacterium e.g., Fibrobacter succinogenes, appeared to be regulating its autolysis via a mechanism involving the proteolytic degradation of autolysins. ${ }^{9,54}$

\section{Endogenous Factors}

Age: DM and CP degradability in calves differs from that of mature cows up to the age of 10-12-weeks after which the calves ability to degrade feed CP approaches that of mature cows This is to be expected due to the young calf's rumen still being in development. ${ }^{60} \mathrm{MBP}$ reaching the duodenum is increasing with age. However, studies based on excretion of purine derivatives (PD) in the urine showed that their excretion was lesser in adult sheep than in the lambs or yearlings because of reduced efficiency of MBP production and increase in proteolytic activity. ${ }^{9}$

Species: Microbial protein production rate estimated by Sodium sulfate in cattle fed straw alone or supplemented with CS or ureamolasses-mineral block (UMMB) licks was 80, 269 and $251 \mathrm{~g} / \mathrm{d}$, respectively. ${ }^{9}$ MBP production in sheep varies from 15 to $35 \mathrm{~g} / \mathrm{kg}$ of fermented OM (FOM). Such large variation within species was due to feeding regime, pattern and feed intake. Although the extent of MBP production varies between species, its efficiency is diet dependent. ${ }^{9}$ If sheep and cattle were fed the same diet, microbial populations would be expected to be similar. However, there are differences because of different outflow rates. ${ }^{61}$

Physiological states: The rumen microorganism appears to provide sufficient protein for maintenance, slow growth and early pregnancy. ${ }^{9}$ In the early lactation, the dry matter intake of highproducing dairy cows is increasing but the energy intake is not sufficient to support milking outputs, therefore the body weight is dropping dramatically. Following peak lactation, the consumption of high-quality diet peaks and milk production drops. During this stage, dairy cows tend to maintain body weight. In the mid and late lactation, energy required for milking is less demanding because of milk production is declining. Dairy cows still need more energy because of pregnancy and energy reserve for the next lactation. Maintaining body condition during the dry period is important for ensuring dairy cows have adequate body reserve for the next lactation. The transition period, defined as three weeks before to three 
weeks after parturition, is characterized by dramatic changes in physiology and nutrient metabolism and imposes great challenges to the dairy cow. ${ }^{62}$ Shifts in the rumen microbial composition of the cows in this period and in general, may alter the rumen fermentation characteristics, influencing parameters like short-chain fatty acid (SCFA) and methane production and thereby affecting feed efficiency of the cow. ${ }^{63}$ Lesser MBP production during pregnancy may relate to poor energetic efficiency of just $20 \%$ for fetal growth. ${ }^{64}$

Multiparous cows tend to have a lower $\mathrm{pH}$ in the rumen than primiparous cows because higher feed intake leads to more fermentation acids produced in the rumen, which is not compensated by increased salivary secretions associated with increased chewing. ${ }^{18}$

Sex: Microbial protein synthesis is not affected by sex being male or female, bull $v$ s heifer and ox $v$ s cows. No suggested evidence that microbial protein synthesis since sex does not affect the intake of DM and digestibility of OM but the intake of digestible OM (DOM) tended to be greater for bulls than for heifers. ${ }^{65}$

Stress: Stress factors is a condition that affects the welfare of the animal. Animal welfare implies that the animals will develop physically and mentally in good conditions, and that nutritional, social, management, health and comfort factors do not adversely affect production. $^{66}$

Health disorders which result from diet stress specially acidogenic diets, in acute acidosis are based on the degree of $\mathrm{pH}$ ruminal decrease which causes great challenge from decreasing the buffering capacity of the ruminal intake, change the population of microorganisms, rumen motility and the systemic fluid balance. ${ }^{67}$

Under heat stress conditions, lactating dairy cows exhibit several physiological responses including a voluntary reduction of feed intake, an increase in maintenance requirements, a decrease in milk yield, and a decline in the quality of milk for manufacturing. Milk protein composition is subject to significant detrimental changes under the effects of heat stress. It is clear that heat stress has an effect on milk protein and casein production and composition that is greater than the indirect effect of reduced intake. ${ }^{68}$

\section{CONCLUSION AND RECCOMMENDATIONS}

\section{Conclusion}

Ruminants have diversified microbial ecosystem consisting of bacteria, ciliate protozoa, anaerobic fungi and bacteriophages. Microbial organism in the rumen plays a key role for the production of single-cell protein and volatile fatty acid for ruminants and they solve issues with nutrition to methanogens. If one factor is not properly managed it causes other factors to worsen the problem on microflora and resulted in affection on the host. Microbial protein synthesis can be affected by many factors that reduce efficiency of MPS in rumen. Factors influencing them are microbial factor, chemical factors and dietary factors even physical factors together with endogenous factor and there is enormous information on how they affect rumen microbial protein synthesis.

If each factor is properly maintained and quantitatively improved microbial protein production they improve the nutrition, health condition, immunity, production, environmental stress as well as methanogens. Quantitative improvement of microbial protein synthesis has improved feed conversion efficiency also increased the synthesis of B-complex vitamins in the rumen by rumen microflora and available to host animal for stress tolerance and metabolism of energy in dairy cattle than qualitative improvement. Since ruminants rely on around $75 \%$ of microbial proteins so they obtain these proteins from them and build their body mass and improve milk yield. So, if we improve factors affecting them we will also get improved milk yield and meat. Therefore, understanding the effect of each factor on microbial protein production is a key for resolution of an animal problem.

\section{Recommendation}

Recommendation is based on:

- Understanding the effect of each factors on microbial protein synthesis and the way to solve those problems should be imposed upon them.

- Use accurate feed nutrient composition value in formulating ration

- Avoid access the ruminants to highly fermentable carbohydrate

- Diet containing a mixture of forages and concentrates should be provided to increases microbial protein synthesis.

\section{REFERENCES |}

1. Kamra DN. Rumen microbial ecosystem. Current Science. 2005; 89: 124-135.

2. Dewhurst RJ, Davies DR, Merry RJ. Microbial protein supply from the rumen. Anim Feed Sci Tech. 2000; 85: 1-21. doi: 10.1016/ S0377-8401(00)00139-5

3. Karsli MA, Russel JR. Effects of source and concentrations of nitrogen and carbohydrate on ruminal microbial protein. Turk $J$ Vet Anim Sci. 2002; 26(2002): 201-207.

4. Hederson G, Cox F, Ganesh S, Jonker A, Young W. Rumen microbial community composition varies with diet and host, but a core micro biome is found across a wide geographical range. Sci Rep. 2015; 14567(2015).

5. Pathak AK. Various factors affecting microbial protein synthesis in the rumen. Veterinary World. 2008; 1(6): 186-189.

6. Clark JH, Klusmeyer TH, Cameron MR. Microbial protein synthesis and flow of $\mathrm{N}$ fraction to the duodenum from the rumen. 
Animal Feed Science and Technology. 1992; 85: 1-2.

7. Sniffen CJ, Robinson PH. Symposium: Protein and fiber digestion, passage, and utilization in lactating cows Microbial growth and flow as influenced by dietary manipulations. J Dairy Sci. 1987; 70: 425-441.

8. Iskenderov TB, Mamedova KQ. Synthesis of Microbial protein in rumen and the influence of different factors on this process. $J$ Fac Vet Med Istanbul Univ. 2013; 39: 131-135.

9. Srinivas B, Krishnamoorthy U. Panoply of microbial protein production in ruminants-A Review. Journal of Animal Nutrition. 2016; 83(4): 331-346.

10. Cerrato-Sánches M, Calsamiglia S, Ferret A. Effects of time at suboptimal $\mathrm{pH}$ on rumen fermentation in a dual-flow continuous culture system. J Dairy Sci. 2007; 90: 1486-1492. doi: 10.3168/jds. S0022-0302(07)71634-X

11. Calsamiglia S, Ferret A, Devant M. Effects of $\mathrm{pH}$ and $\mathrm{pH}$ fluctuations on microbial fermentation and nutrient flow from a dualflow continuous culture system. J Dairy Sci. 2002; 85: 574-579. doi: 10.3168/jds.S0022-0302(02)74111-8

12. Strobel HJ, Russell JB. Effect of $\mathrm{pH}$ and energy spilling on bacterial protein synthesis by carbohydrate-limited cultures of mixed rumen bacteria. J Dairy Sci. 1986; 69: 2941-2947

13. Verbic J, Ørskov ER, Žgajnar J, et al. The effect of method of forage preservation on the protein degradability and microbial protein synthesis in the rumen. Anim Feed Sci Technol. 1999; 82: 195212. doi: 10.1016/S0377-8401(99)00102-9

14. Erdman RA. Dietary buffering requirements of the lactating dairy cow: A review. J Dairy Sci. 1988; 71: 3246-3266. doi: 10.3168/ jds.S0022-0302(88)79930-0

15. Stokes SR, Hoover WH, Miller TK, Blauweikel R. Ruminal digestion and microbial utilization of diets varying in type of carbohydrates and protein. J Dairy Sci. 1991; 74: 871-881. doi: 10.3168/ jds.S0022-0302(91)78236-2

16. Owens FN, Zinn R. Protein metabolism of ruminant animals. In: Church DC, ed. The Ruminant Animal, Digestive Physiology And Nutrition. New Jersey, USA: Prentice Hall; 1988: 227-249.

17. Zhao JY, Shimojo M, Goto I. The effects of feeding level and roughage/concentrate ratio on the measurements of protein degradability of two tropical forages in the rumen of goats, using the nylon bag technique. Anim Feed Sci Technol. 1993; 41: 261-269. doi: 10.1016/0377-8401(93)90001-Z

18. Maekawa M, Beauchemin KA, Christensen DA. Chewing activity, saliva production, and ruminal $\mathrm{pH}$ of primiparous and multiparous lactating dairy cows. J Dairy Sci. 2002; 85: 1176-1182. doi: 10.3168/jds.S0022-0302(02)74180-5
19. Storm AC, Kristensen NB, Røjen BA, Larsen M. Technical note: A method for quantification of saliva secretion and salivary flux of metabolites in dairy cows. J Anim Sci. 2014; 91: 5769-5774. doi: $10.2527 /$ jas.2013-6865

20. James BR, Dombrowski DB. Applied and environmental microbiology. 1980; 39(3): 604-610.

21. West JW, Coppock CE, Milam KZ, Nave DH, Labore JM, Rowe LD . Potassium carbonate as a potassium source and dietary buffer for lactating Holstein cows during hot weather. J Dairy Sci. 1987; 70(2): 309-320. doi: 10.3168/jds.S0022-0302(87)80012-7

22. Pourazad P, Khiaosa-Ard R, Qumar M, et al. Transient feeding of a concentrate-rich diet increases the severity of subacute ruminal acidosis in dairy cattle. J Anim Sci. 2016; 94(2): 726-738. doi: 10.2527/jas.2015-9605

23. Kim DH, McLeod KR, Klotz JL, Koontz AF, Foote AP, Harmon DL. Evaluation of a rapid determination of fasting heat production and respiratory quotient in Holstein steers using the washed rumen technique. J Anim Sci. 2014; 91: 4267-4276. doi: $10.2527 /$ jas.2012-5595

24. Yazdi MH, Mirzaei-Alamouti HR, Amanlou H. Effects of heat stress on metabolism, digestibility, and rumen epithelial characteristics in growing holstein calves. J Anim Sci. 2016; 94(1): 77-89. doi: $10.2527 /$ jas.2015-9364

25. Chaucheyras-Durand F, Walkera ND, Bach A. Effects of active dry yeasts on the rumen microbial ecosystem: Past, present and future. Anim Fd Sci Technol. 2008; 145(1-4): 5-26. doi: 10.1016/j. anifeedsci.2007.04.019

26. Ellis JE, Williams AG, Lloyd D. Oxygen by ruminal microorganisms: Protozoal and bacterial contributions. Appl Environ Microbiol. 1989; 55: 2583-2587.

27. Jasi MUMd, Haque KZ, Jasimuddin KMd, Hasan MdK. Dynamics of microbial protein synthesis in the rumen. Annals of Veterinary and Animal Science. 2015; 2(5): 117-131

28. Agricultural and Food Research Council. Agricultural and Food Research Council, Technical Committee on Responses to Nutrients: Report No. 9: Nutritive Requirements of Ruminant Animals: Protein. 1992; 62: 787-835.

29. National Research Council. Nutrient Requirements of Dairy Cattle. $7^{\text {th }}$ ed. Washington, DC, USA: National Academic Press; 2001.

30. Evans E. An evaluation of the relationships between dietary parameters and rumen solid turnover rate. Canadian Journal of Animal Science. 1981; 61: 91-96. doi: 10.4141/cjas81-014

31. Meng Q1, Kerley MS, Ludden PA, Belyea RL. Fermentation substrate and dilution rate interact to affect microbial growth and efficiency. I Anim Sci. 1999; 77: 206-214. doi: 10.2527/1999.771206x 
32. Evans E. Practicalities of balancing diets for amino acids. Paper presented at: TRI-state Dairy Nutrition Conference, Ohio State University; April 8-9, 2003; Columbus, Ohio, USA. 133-140.

33. Gomes MJ, Hovell FD, Chen XB, Nengomasha EM, Fikremariam D. The effect of starch supplementation of straw on microbial protein supply in sheep. Anim Feed Sci Technol. 1994; 49: 277-286. doi: 10.1016/0377-8401(94)90052-3

34. Zadeh JB, Moradikor Z, Moradikor N. Synchronization of energy and protein on supply synthesis microbial protein. Int J $A d v$ Biol Biom Res. 2013; 1: 594-600.

35. Cabrita ARJ, Dewhurs RJ, Abreu JMF, Fonseca AJM. Evaluation of the effects of synchronizing the availability of $\mathrm{N}$ and energy on rumen function and production responses of dairy cows. Anim. Res. 2005; 55: 1-24. doi: 10.1051/animres:2005045

36. Karsli M, Russel JR. Effects of some dietary factors on rumen microbial protein synthesis. Turk J Vet Anim Sci. 2001; 25: 681-686.

37. Russell JB. The energy spilling reaction of bacteria and other organisms. J Mol Micro biol Biotechnol. 2007; 13: 1-11. doi: $10.1159 / 000103591$

38. Van Kessel JS, Russell JB. The effect of amino nitrogen on the energetic of ruminal bacteria and its impact on energy spilling. J Dairy Sci. 1996; 79: 1237-1243. doi: 10.3168/jds.S00220302(96)76476-7

39. Sylvester JT, Karnati SK, Yu Z, Newbold CJ, Firkins JL. Evaluation of a real-time PCR assay quantifying the ruminal pool size and duodenal flow of protozoal nitrogen. J Dairy Sci. 2005; 88: 2083-2095. doi: 10.3168/jds.S0022-0302(05)72885-X

40. Ashwin K, Srinivas B. Effect of Vitamin Supplements on in Vitro Fermentation, in Vivo Microbial Protein Synthesis and Milk Production in Deoni Cows. [dissertation]. Bangalore, India: Southern Regional Station, National Dairy Research Institute; 2015.

41. Broudiscou L, Jouany JP. Reassessing the manipulation of protein synthesis by rumen microbes. Reprod Nutr Dev. 1995; 35: $517-$ 535. doi: $10.1051 /$ rnd:19950505

42. Faniyi TO, Adewumil MK, Prates RE, Ayangbenro AS. Effect of herbs and spices (plant extracts) on rumen microbial activities. PUBVET. 2016; 10: 477-486. doi: 10.22256/pubvet.v10n6

43. Callaway TR, Edrington TS, Rychlik JL, et al. Ionophores: Their use as ruminant growth promotants and impact on food safety. Curr Issues Intest Microbiol. 2003; 4: 43-51.

44. Farquhar AS. Kinetics of Alfalfa Nitrogen and Cell Wall Disappearance from Ruminallyincubated Dacron Bags. [dissertation]. Amsterdam, Netherlands: Iowa State University; 1985.

45. Elizalde JC, Cremin JD, Faulkner DB, Merchen NR. Perfor- mance and digestion by steers grazing tall Fescue and supplemented with energy and protein. J Anim Sci. 1998; 76: 1691-1701. doi: $10.2527 / 1998.7661691 x$

46. Carruthers VR, Neil PG, Dalley DE. Effect of altering the non-structural: Structural carbohydrate ratio in a pasture diet on milk production and ruminal metabolites in cows in early and late lactation. Anim Sci. 1997; 64, 393-402. doi: 10.1017/ S1357729800015988

47. Harstad OM, Vik-Mo L. Estimation of microbial and undegraded protein in sheep on grass silage based diets. Acta Agriculturñ Scandinavica. 1985; 25: 37-48.

48. Rooke JA, Brett PA, Overend MA, Armstrong DG. The energetic efficiency of rumen microbial protein synthesis in cattle given silage-based diets. Anim Feed Sci Technol. 1985; 13: 255-267. doi: 10.1016/0377-8401(85)90028-8

49. Charmley E, Veira DM, Butler G, Aroeira L, Codagnone HCV. The effect of frequency of feeding and supplementation with sucrose on ruminal fermentation of alfalfa silage given adlibitum or restricted to sheep. Can J Anim Sci. 1991; 71: 725-737. doi: 10.4141/ cjas91-088

50. Klieve AV, Bain PA, Yokoyama MT, Ouwerkerk D, Forster RJ, Turner AF. Bacteriophages that infect the cellulolytic ruminal bacterium Ruminococcusalbus AR67. Lett Appl Microbiol. 2004; 38: 333-338. doi: 10.1111/j.1472-765X.2004.01493.x

51. Klieve AV, Gilbert RA. Bacteriophage populations. In: Makkar HPS, McSweeney CS, eds. Methods in Gut Microbial Ecology for Ruminants. New York City, USA: Springer Publishing; 2005: 129-137.

52. Firkins JL, Weiss WP, Piwonka EJ. Quantification of intraruminal recycling of microbial nitrogen using nitrogen-15. J Anim Sci. 1992; 70(10): 3223-3233. doi: 10.2527/1992.70103223x

53. Swain, RA, Klieve AV, Nolan JV. Factors affecting the rumen bacteriophage population. Proc. Aust. Sot. Anim. Prod. 1996; 21: 408.

54. Williams AG, Coleman GS. The Rumen Protozoa. New York, USA: Springer Publishing; 1992.

55. Belanche A, de la Fuente G, Pinloche E, Newbold CJ, Balcells $J$. Effect of diet and absence of protozoa on the rumen microbial community and on the representativeness of bacterial fractions used in the determination of microbial protein synthesis. J Anim Sci. 2012; 90: 3924-3936. doi: 10.2527/jas.2011-4802

56. Karnati SKR., Sylvester JT, Ribeiro CVDM, Gilligan LE, Firkins JL. Investigating unsaturated fat, monensin, or bromoethanesulfonate in continuous cultures retaining ruminal protozoa. I. Fermentation, biohydrogenation, and microbial protein synthesis. $J$ Dairy Sci. 2009; 92: 3849-3860. doi: 10.3168/jds.2008-1436

57. Demeyer DI, Fiedler D, DeGraeve KG. Attempted induction 
of reductive acetogenesis into the rumen fermentation in vitro. Reprod Nutr Dev. 1996; 36: 233-240. doi: 10.1051/rnd: 19960301

58. Stanford K., Bach SJ, Stephens TP, Mcallister TA. Effect of rumen protozoa on Escherichia coli O157:H7 in the rumen and feces of specifically faunated sheep. J Food Prot. 2010; 73: 2197-2202. doi: 10.4315/0362-028X-73.12.2197

59. Carlson SA, Sharma VK., McCuddin ZP, Rasmussen MA, Franklin SK. Involvement of a Salmonella genomic island 1 gene in the rumen protozoan-mediated enhancement of invasion for multiple-antibiotic-resistant Salmonella entericaserovar Typhimurium. Infect Immun. 2007; 75: 792-800. doi: 10.1128/IAI.00679-06

60. Holtshausen L, Cruywagen CW. The effect of age on in saccoestimates of rumen dry matter and crude protein degradability in veal calves. S. Afr. J. Anim. Sci. 2000; 30: 212-219.

61. Ørskov ER, Hughes-Jones M, Elimam ME. Studies on degradation and outflow rate of protein supplements in the rumen of sheep and cattle. Livest. Prod. Sci. 1983; 10: 17-24. doi: 10.1016/0301-6226(83)90003-9

62. Bell AW. Regulation of organic nutrient metabolism during transition from late pregnancy to early lactation. J Anim Sci. 1995; 73: 2804-2819. doi: 10.2527/1995.7392804x

63. Wang X, Li X, Zhao C, et al. Correlation between composition of the bacterial community and concentration of volatile fatty acids in the rumen during the transition period and ketosis in dairy cows. Appl Environ Microbiol. 2012; 78: 2386-2392. doi: 10.1128/ AEM.07545-11

64. Jewell KA, McCormick CA, Odt CL, Weimer PJ, Suen G. Ruminal bacterial community composition in dairy cows is dynamic over the course of two lactations and correlates with feed efficiency. Appl Environ Microbiol. 2015; 81: 4697-4710. doi: 10.1128/ AEM.00720-15

65. Pratesa LL, Valadaresa RFD, Valadares Filhob SC, et al. Investigating the effects of sex of growing Nellore cattle and crude protein intake on the utilization of recycled $\mathrm{N}$ for microbial protein synthesis in the rumen by using intravenous $15 \mathrm{~N} 15 \mathrm{~N}$-urea infusion. I Ani Fed Sci. 2017; 231: 119-130. doi: 10.1016/j.anifeedsci.2017.06.014

66. Carenzi C, Verga M. Animal welfare: Review of the scientific concept and definition. Ital J Anim Sci. 2009; 8: 21-30. doi: 10.4081/ ijas.2009.s1.21

67. Minuti A, Ahmed S, Trevisi E, et al. Experimental acute acidosis in sheep: Consequences on clinical, rumen, and gastrointestinal permeability conditions and blood chemistry. I Anim Sci. 2014; 92: 3966-3077. doi: 10.2527/jas.2014-7594

68. Kadzere CT, Murphy MR, Silanikove N, Maltz E. Heat stress in lactating dairy cows: A review. Livest. Prod. Sci. 2002; 77: 59-91. doi: 10.1016/S0301-6226(01)00330-X 